\title{
REACTUALIZATION OF THE FUNCTION AND ROLE OF PRINCIPALS IN SENIOR HIGH SCHOOLS (SMA) IN LUWU REGENCY, INDONESIA
}

\author{
Basmin Mattayang ${ }^{1}$, Husain Syam ${ }^{2}$, Haedar Akib ${ }^{3}$, Andi Kasmawati ${ }^{4}$, Patahuddin $^{5}$ \\ Email: basminmtyg@gmail.com ${ }^{1}$, husainsyam@unm.ac.id ${ }^{2}$, \\ haedar652002@yahoo.com.au ${ }^{3}$, kasmawatiamri@yahoo.co.id ${ }^{4}$, \\ patahuddin@unm.ac.id ${ }^{5}$ \\ ${ }^{1-5}$ Universitas Negeri Makassar, Makassar, Indonesia
}

\begin{abstract}
The urgency and significance of the research on the actualization of functions and roles of the Principal is based on the assumption that "school success is the success of the school principal" carrying out their main tasks and functions, as expected in the implementation of Minister of National Education Regulation Number 13 of 2007 concerning Standards Principal / Head of Madrasah. The article from this research explains the actualization of the functions and roles of high school principals in Luwu Regency, South Sulawesi Province, Indonesia. The research method used is a survey. Data was collected using observation, questionnaires, interviews and documentation techniques. Data were processed and analyzed using quantitativedescriptive statistics with the spider curve model. The results showed that the actualization of the function and role of principals in high schools in Luwu Regency on an average "effective category" was seen from the behavior performance of principals as educators, managers, administrators, supervisors, leaders, innovators, motivators and entrepreneurs.
\end{abstract}

Keywords: Function and role of school principals, school-based management, community-based schools.

\section{INTRODUCTION}

Re-actualization (realizing, re-manifestation) the function and role of the principal (Akib, 2008; Dharma \& Akib, 2009; Menteri Pendidikan Nasional Republik, 2007; Sudrajat, 2008) is a consequence of the successful implementation of capacity building programs in educational organizations. The essence and orientation of the implementation are inspired and motivated by the positive assumption that "school success is the success of the principal" and vice versa, school failure is the failure of the principal to carry out the main tasks, functions and roles. 
INTERNATIONAL CONFERENCE ON PUBLIC ORGANIZATION

ASIA PACIFIC SOCIETY FOR PUBLIC AFFAIRS (APSPA)

The need for the actualization of the functions and roles of principals (Akib, 2008) and mastery of the competence of principals (Dharma \& Akib, 2009; Jufri, Akib, Ridjal, Sahabuddin, \& Said, 2018; Saggaf, Salam, \& Rifka, 2017; Salam \& Akib, 2014; Sudrajat, 2008; H. Syam, Akib, Patonangi, \& Guntur, 2018) in good school governance (GSG, Syam et al., 2018) relates to the negative impacts caused by interventions from various parties that often raise the symptoms of a kind of "learned disability" (Asumah \& Nagel, 2014), namely the phenomenon of powerlessness at the level of the education unit and the principal. Therefore, efforts to reactivate the functions and roles of school principals need to involve a component of governance outside the country, especially the business sector (private) and the industrial world (DUDI) and the community. The direction and goals of governance are crystallized in the principle of "Community Based Schools" (Smith \& Sobel, 2014; Warren, Hong, Rubin, \& Uy, 2009) and the pillars of "School-Based Management" (Cheng, 2013; Dimmock, 2013; Murphy \& Beck, 1995). The pillars of school-based management include management, teaching-learning processes (learning) and community participation. Similarly, it is understood that the people in charge of education are parents, government and society. Besides that, the most important thing in this article is to actualize the main tasks, functions and roles of principals in the framework (acronym) of EMASLIMEF - educator, managerial, administrator, supervisor, leader, innovator, motivator, entrepreneur, formal officer (Danim \& Suparno, 2008; Dharma \& Akib, 2009; Usman, 2015).

According to experts (Akib, 2008; Danim \& Suparno, 2008; Wahjosumidjo, 2005) that school principals need to have the competencies required to realize their school's vision and mission, what principals need is a reliable ability to carry out their tasks principal, function and role. Although the appointment of school principals is carried out in a planned and systematic manner, even appointed from teachers who are experienced or may have long served as vice principals, but it does not automatically make professional principals carry out their main tasks and functions.

Other reasons that underlie the need for re-actualization of the main tasks, functions and roles of principals are based on the views of experts (Cheng, 2013; Cranston, 2002; Dimmock, 2013; Dunham, 2003; Everard, Morris, \& Wilson, 2004; Murphy \& Beck, 1995; Smith \& Sobel, 2014) that the optimal target of achieving educational quality improvement in each educational unit or school can be realized 
when the entire process includes the implementation of management functions, namely planning, implementation, monitoring, evaluation and reporting carried out intensively, comprehensively, measurably and scheduled. The principal should have competence by the Republic of Indonesia Minister of National Education Regulation Number 13 of 2007 concerning Competency Standards for Principals / Madrasas (Menteri Pendidikan Nasional Republik, 2007), namely managerial competence, entrepreneurship, supervision, personality and social. As managers, principals must have the ability and skills to create school-based quality improvement programs that are targeted and targeted by maximizing the strengths and opportunities they have and overcoming weaknesses and threats that might be a hindrance achievement of school goals. Therefore, the principal needs to implement the principles of a sustainable learning organization and build the participation of school people and the community through the school committee.

According to Syam et al., (2018) that strengthening the pillars of school-based management and community-based schools is needed because so far the involvement of education stakeholders (teachers, principals, students, parents, school committees, community members) is often only understood as a technical process administrative only, not as a continuous process of good school governance. Therefore, the article from this study explains the re-realization of the functions and roles of principals in senior high schools in Luwu Regency.

\section{LITERATURE REVIEW}

In essence, the importance of the function and role of school principals in good school governance/GSG (H. Syam et al., 2018) supports expert understanding and the assumption that, "school success is the success of the principal" (Akib, 2008; Danim \& Suparno, 2008; Usman, 2015; Wahjosumidjo, 2005). Therefore, school principals need to have the competencies required to realize their school's vision, mission and goals. The actualization of functions and roles of principals is translated into the acronym EMASLIMEF, namely educators, managers, administrators, supervisors, leaders, innovators, motivators, entrepreneurs, formal leaders (Akib, 2008; Danim \& Suparno, 2008; Wahjosumidjo, 2005).

Principal as Educator. Principals are teachers who are given additional assignments as principals (Minister of National Education of the Republic of 
INTERNATIONAL CONFERENCE ON PUBLIC ORGANIZATION

ASIA PACIFIC SOCIETY FOR PUBLIC AFFAIRS (APSPA)

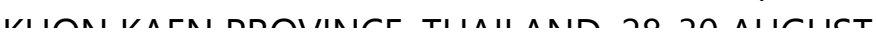

Indonesia/ Menteri Pendidikan Nasional Republik Indonesia, 2007). As educators, principals are the main actors in building school culture and learning culture of school organizations (Asumah \& Nagel, 2014; Duhan, Levy, \& Powell, 2001; Engels, Hotton, Devos, Bouckenooghe, \& Aelterman, 2008; Everard et al., 2004; Singh \& Dali, 2013). The principal seeks to improve his performance related to the quality of learning carried out by the teacher in his school by: 1) Engaging teachers regularly and proportionally in upgrading or training; provide opportunities for teachers to study further; 2) Move the student learning outcomes evaluation team to work actively and be announced; 3) Using study time effectively at school.

Principal as Manager. Management (as a function and process) is essentially an activity of planning, organizing, carrying out, leading and controlling the business of members of the organization, and utilizing all organizational resources to achieve the stated goals (Cheng, 2013; Cranston, 2002; Danim \& Suparno, 2008; Dimmock, 2013; Duhan et al., 2001; Everard et al., 2004). As managers, principals must be willing and able to utilize school resources to realize their vision, mission, as a reference to achieving school goals. The principal must be able to deal with various problems in school, analytical thinking, conceptual and intermediary interpreters in solving various problems (conflicts), and making decisions that satisfy school stakeholders. Likewise, school principals must provide opportunities for education staff to improve their professional abilities which are carried out persuasively and from the heart to heart. In this case the principal is guided by the principle of purpose, principle of excellence, the principle of consensus, the principle of unity, the principle of unity, the principle of empiricism, the principle of intimacy, and the principle of integrity.

Principal as Administrator. Principals as administrators carry out functions in managing the school administration system which includes office administration (administration), finance, facilities and markets, staffing, student affairs and alumni relations and so on (Akib, 2008; Cheng, 2013; Sudrajat, 2008). The principal needs the ability to plan, manage the curriculum, manage the administration of archives, financial administration and other school administration functions. This activity is carried out effectively, efficiently and sustainably to support school productivity. The principal must be able to describe the above abilities into operational tasks. 
INTERNATIONAL CONFERENCE ON PUBLIC

ORGANIZATION

ASIA PACIFIC SOCIETY FOR PUBLIC AFFAIRS (APSPA)

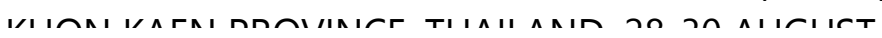

*APSPA"

Principal as Supervisor. The principal supervises the work carried out by teachers and education staff. A number of education experts (Akib, 2008; Cheng, 2013; Cranston, 2002; Danim \& Suparno, 2008; Everard et al., 2004; Shermon, 2005; Sudrajat, 2008) agree that supervision is a process specifically designed to help teachers and supervisors learn the daily tasks at school, to use their knowledge and abilities to provide better service to parents of students and school residents, and try to make the school a more effective learning community. Supervision and control by the principal of the teacher through "clinical supervision" aims to improve the professional ability of the teacher and improve the quality of learning, so that it fits into the acronym PAIKEMB (pembelajaran/learning, aktif/ active, inovatif/innovative, kreatif/ creative, efektif/ effective, menyenangkan/fun, bermakna/ meaningful). The principal as a supervisor needs to pay attention to the principles: 1) consultative, collegial and not hierarchical relationships; 2) implemented democratically; 3) centered on teachers and education staff; 4) based on the needs of teachers and education staff; and 5) is professional assistance.

Principal as Leader. Principals as leaders are carried out through guidance and supervision, increasing the willingness and ability of teachers and education personnel, opening communication (multi-direction) and delegating tasks. The ability of principals as leaders is based on aspects of personality, knowledge of education staff, school vision and mission, ability to make decisions and communication skills (Akib, 2008; Cranston, 2002; Danim \& Suparno, 2008; Johnson \& Short, 1998; Pihie, Asuimiran, \& Bagheri, 2014; Singh \& Dali, 2013). Then, the principal's personality as a leader is reflected in his nature which is: 1) honest, 2) confident, 3) responsible, 4) brave decision and moderate risk, 5) big soul, 6) stable emotions, and 7) can imitate. At the level of implementation, principals as leaders, at least seen from several types, styles or ways of leadership that are applied, namely democratic, authoritarian, free, transformational, transactional, developmental.

Principal as an Innovator. The principal in order to carry out his role and function as an innovator, has the right strategy to establish harmonious relationships with the environment (internal, external, events), create new ideas, integrate each activity, set an example to teachers and education staff and develop conventional learning models and modern or 21st century learning (Akib, 2008; Cheng, 2013; Cranston, 2002; Danim \& Suparno, 2008; Dempster, 2001; Dharma \& Akib, 2009; Dunham, 
2003; Ichijo, 2007; Pihie et al., 2014). The principal as an innovator in increasing the professionalism of teachers and education staff is reflected in the way he does work constructively, creatively, delegatively, integratively, rationally, objectively, pragmatically, exemplary, disciplined, adaptive and flexible.

Principal as a Motivator. As a motivator, the principal must have the right strategy to motivate teachers and education staff in carrying out their duties and functions (Akib, 2008; Danim \& Suparno, 2008; Mestry \& Grobler, 2004; A. Syam, Akib, Yunus, \& Hasbiah, 2018; Wahjosumidjo, 2005; Williams, 2008; Zahra, Nielsen, \& Bogner, 1999). Motivation can be grown through the regulation of the school's physical environment, work atmosphere, discipline, persuasion, strengthening, effective appreciation and the provision of various learning resources through the development of a Learning Resource Center that is appropriate to the situation (physical, geographical, psychological, social, cultural) of the school environment.

Principal as an Entrepreneur. The principal as an entrepreneur is needed to direct school citizens as learners and their schools as effective learning organizations. The principal as an entrepreneur refers to nature, character and characteristics inherent in him in the form of a strong will to realize and develop the creative and innovative ideas that are held into valuable activities. Entrepreneurial spirit and attitude are not only owned by entrepreneurs, but also every school principal who thinks creatively and acts innovatively and productively in organizing education and managing his school (Dharma \& Akib, 2009; Duhan et al., 2001; Jufri et al., 2018; Pihie et al., 2014; A. Syam et al., 2018; H. Syam et al., 2018; Zahra et al., 1999).

Principal as a Formal Officer. Position or leadership in schools occurs through two forms, namely formal leadership and informal leadership (Akib, 2008; Cranston, 2002; Danim \& Suparno, 2008; Mestry \& Grobler, 2003, 2004; Wahjosumidjo, 2005). Formal leadership occurs when formal positions or authorities in school organizations are filled by people (teachers) who are appointed or selected through a selection process. Whereas informal leadership occurs when the position of leader in a school organization is filled by people who appear and influence other people, because special skills or competencies possessed, or the resources they have been felt to be able to solve problems in schools and meet the needs of school residents. 


\section{RESEARCH METHODS}

Survey research (Singarimbun \& Efendi, 1996) focuses on re-actualization of the main tasks, functions and roles of principals (Akib, 2008; Engels et al., 2008; Johnson \& Short, 1998; Mestry \& Grobler, 2003, 2004; Singh \& Dali, 2013; H. Syam et al., 2018) at the high school (SMA) locus as a learning organization (Gilley \& Maycunich, 2000; Kuehn, 2008; Marquardt, 2011) in Luwu Regency, Indonesia. The focus of research on the main tasks, functions and roles of principals is as educators, motivators, administrators, supervisors, leaders, innovators, entrepreneurs abbreviated as EMASLIME.

The collection of primary and secondary data is carried out using data collection techniques as follows. Observation techniques, used by observing, identifying and recording the accuracy (quality, quantity) and suitability of quantitative data regarding all items in the re-actualization (re-manifestation) of the function and role of the principal in conducting good school governance. The questionnaire technique, used to collect primary data in the form of statements and written questions submitted to respondents (research subjects). Data collected is an assessment of subjects who express opinions, attitudes, experience individually or in groups. This technique is also used to ask important aspects regarding the mastery of the competency of the principal in carrying out their functions and roles. Documentation techniques, used to study important documents that support clarity of evidence regarding regulations, activity guidelines and written documents regarding the aspects studied. Interviewing techniques, carried out by researchers on the number of key informants determined and informants in general to obtain complete information. Interviews were conducted on information representing regional organizations (Organisasi Perangkat Daerah/OPD) in the education sector (Education Office, Education Department), Educational Quality Assurance Agency (Lembaga Penjaminan Mutu Pendidikan LPMP), private sector (community) and informants representing educational figures. Analysis of research data was carried out using descriptive statistical analysis techniques (Singarimbun \& Efendi, 1996; Sugiyono, 2010, 2006) to be presented through the spider curve model. 


\section{RESULT AND DISCUSSION}

In general, the results of the study show that the actualization of the main tasks, functions and roles of principals in senior high schools in Luwu Regency is on average "good", judging from the behavior of principals as educators, managers, administrators, supervisors, leaders, innovators, motivator and entrepreneur. The presentation of the results of data analysis regarding the implementation of the function and role of the principal is presented in the order of the level of performance behavior categories.

Principals in senior high schools (public and private) in Luwu Regency are teachers who are given additional assignments as school principals (Menteri Pendidikan dan Kebudayaan, 2018) after they fulfill the requirements and have passed the selection (test) as the principal. The implementation of the main tasks, functions and roles of principals as administrators occupies the first good category. The principal organizes various school administration functions which include arranging student administration that starts from planning the acceptance of new prospective students until students become alumni; organize the curriculum (including local content curriculum) so as to be able to follow the dynamics of the development and demands of the community; organize financial administration in a transparent and accountable manner; regulate the use of facilities and infrastructure as well as learning media in schools efficiently, effectively and sustainably; organize staffing including the ratio of the number of teachers, employees and students proportionally; and other school administration functions in the "strict school company" activity unit. Reactualization of the function and role of the principal as administrator is carried out by a "head of business", as the expert views (Akib, 2008; Cheng, 2013; Sudrajat, 2008) that principals as administrators carry out functions in managing the school administration system which includes office administration, finance, facilities and markets, staffing, student affairs and alumni relations and so on. This activity is carried out effectively, efficiently and sustainably to support school productivity.

The implementation of the principal tasks and functions and roles of the principal as an educator is an embodiment of identity and the locus of developing managerial abilities of teachers who do additional tasks. The performance of the school principal's task as an educator is classified as "good and very good" because the 
INTERNATIONAL CONFERENCE ON PUBLIC ORGANIZATION

ASIA PACIFIC SOCIETY FOR PUBLIC AFFAIRS (APSPA)

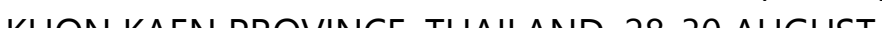

*APSPA

principal can create the condition of the school as a center of formal learning and the school as the locus of inheritance of cultural values. Principals in senior high schools in Luwu Regency have experience as teachers or educators, so that the "character of educators" they have makes it easier to teach or give persuasion to teachers, school administration staff and students to be more aware of the task. Obligations and responsibilities of each. The teacher as an educator has been able to realize his mastery of personal, social, pedagogical and professional competence. School administration staff can serve and satisfy school residents. Likewise students are aware of the task of learning to pass and pretend. The behavior of principals as educators reinforces the views of experts (Asumah \& Nagel, 2014; Dunham, 2003; Engels et al., 2008; Everard et al., 2004; Singh \& Dali, 2013) that principals build a learning culture of school organizations. Principals improve their performance as educators by including proportional teachers in upgrading, training or further study and likewise motivating students to take advantage of their study time at school.

The implementation of the principal tasks, functions and roles of the principal as a leader is a manifestation of "personal, social and institutional responsibility. The behavioral performance of principals in senior high schools in Luwu Regency is relatively good because it can give effect to the participation of teachers, staff and students. The principal's example reinforces the views of experts (Akib, 2008; Cranston, 2002; Danim \& Suparno, 2008; Johnson \& Short, 1998; Pihie et al., 2014; Singh \& Dali, 2013) that at the implementation level, principals as a leader, at least it can be seen from several types, styles or ways of leadership that are applied with generic characteristics, namely principals who are democratic, transformational and "fatherly" style for those of the male sex and "motherly" for the female sex. The fatherly or maternal characteristics of the principal are not only because they are called or called "Father / Mother" but also because the principal shows the character of behavior as a person who is "elder", "respected" and "imitated."

The implementation of the principal tasks, functions and roles of the principal as an entrepreneur is based on regulations concerning the principal/madrasah competency standards (Menteri Pendidikan Nasional Republik, 2007). Principals in senior high schools in Luwu are quite creative and innovative in carrying out their functions and roles, both in utilizing human resources (teachers, employees, students, parents) owned and in managing and utilizing environmental resources for 
the benefit of school residents. The principal gives an example of productive behavior by inviting parents of students and successful alumni to contribute to school activities. The principal empowers teachers and their students so that the local content curriculum is carried out according to the potential and the school environment. According to experts and researchers (Dharma \& Akib, 2009; Dunham, 2003; Jufri et al., 2018; Pihie et al., 2014) that principals as entrepreneurs refer to the nature, character and characteristics inherent in themselves in the form of a strong will to realize and develop the creative and innovative ideas they have into valuable activities. In other words, principals who think creatively and act innovatively and productively in carrying out education and managing schools are the actualization of functions and their competency-based roles.

The implementation of the principal tasks, functions and roles of the principal as a manager can be seen through the duties and functions of the principal in planning, implementing, supervising, evaluating and following up on all activities in the senior high schools in Luwu Regency. The role of the principal as a manager is also seen through his ability to direct and account for the consequences of activities that are "in the name of his school". In principle, the implementation of the duties and functions of the principal is in accordance with the views of experts (Cheng, 2013; Cranston, 2002; Danim \& Suparno, 2008; Dimmock, 2013; Dunham, 2003; Everard et al., 2004) that, as principal managers must be willing and able to utilize school resources in order to realize the vision, mission, as a reference to achieving school goals. The principal must be able to deal with various problems in the school, think analytically, conceptually and interpreters of conflict, and make decisions that satisfy school stakeholders.

The implementation of the main tasks, functions and roles of principals in senior high schools in Luwu Regency as a motivator is the actualization of his identity as a teacher given an additional mandate or assignment. The teacher's character inherent in the principal always gives motivation, persuasion and appreciation to other people (fellow teachers, employees or students). According to experts and researchers (Akib, 2008; Danim \& Suparno, 2008; Mestry \& Grobler, 2003; A. Syam et al., 2018; Wahjosumidjo, 2005; Williams, 2008; Zahra et al., 1999), that the motivational function of the principal can be actualized through the arrangement of the school's physical environment, work atmosphere, discipline, persuasion, strengthening, 
effective appreciation and the provision of various learning resources that are appropriate to the situation and conditions (physical, geographical, psychological, social, cultural) school environment.

According to the informant (Interview, 2019) that, the principal tasks and functions of the principal as a motivator for school citizens are the actualization of the identity of the people of South Sulawesi who respect local cultural values: sipakatau (humanizing each other), sipakainge (reminding each other) and sipakalebbi (mutual respect) or better known as the 3-S philosophy (Khotimah, 2013; Maida, 2017; Unru \& Ismail, 2018). In this philosophy of life implied the meaning of "motivating each other" with each other as fellow human beings. According to Unru \& Ismail (2018) that, sipakatau, sipakainge, sipakalebbi is the proverb of the ancestors of the BugisMakassarese people who were used as culture in social life. Sipakatau is an attitude that humanizes a whole person in any condition regardless of one's social status, education and caste. Sipakalebbi is a form of appreciation to someone or mutual respect for one another. Sipakainge has the meaning of reminding each other to achieve sustainability in life. Furthermore, the informant stated that, there is a life philosophy of the Bugis-Makassar people who are full of motivational meanings, as the description of the contents of Akib (2014) is titled: "Tellu Cappa" as the Organizational Motivation and Image Theory. According to Akib that tellu cappa means "three ends" namely "the ends/tip of the knife/ badik" (motivation to uphold honor), "the tip of the tongue" (motivation to show intelligence and diplomatic expertise) and "the tip of men" (underlying the drive to unite and expand relationships) family/kinship).

The implementation of the principal tasks, functions and roles of the principal as a supervisor is carried out with a "clinical supervision" approach, both concerning academic activities (learning) and managerial or administrative activities in his school. Clinical supervision was applied by school principals in Luwu Regency because they agreed with "collegial and professional principles" as fellow educators so that the learning process and results increased. It is understood that, supervision and control by the headmaster of the teacher through "clinical supervision" aims to improve the teacher's professional abilities and improve the quality of learning. Principals as supervisors need to pay attention to the principles of consultative, collegial, democratic relations, teacher-centered and educational personnel, as 
INTERNATIONAL CONFERENCE ON PUBLIC ORGANIZATION

ASIA PACIFIC SOCIETY FOR PUBLIC AFFAIRS (APSPA)

needed, are professional assistance (Akib, 2008; Cranston, 2002; Danim \& Suparno, 2008; Dunham, 2003; Everard et al., 2004; Sudrajat, 2008).

The implementation of the main tasks, functions and roles of principals as innovators in senior high schools in Luwu Regency showed the lowest good category. The behavior of principals is demonstrated through their ability to realize "new ideas" that are understood or adopted from other schools, principals' best practices in supporting 21st-century learning, the results of sharing in "Principal Working Group" activities or "Principal Working Meeting" activities. "A number of experts and writers (Akib, 2008; Cheng, 2013; Cranston, 2002; Danim \& Suparno, 2008; Dempster, 2001; Dharma \& Akib, 2009; Duhan et al., 2001; Ichijo, 2007) agree that principals as innovators in increasing the professionalism of teachers and education personnel are reflected in the way they do work constructively, creatively, delegatively, integratively, rationally, objectively, pragmatically, exemplary, disciplined, adaptive and flexible.

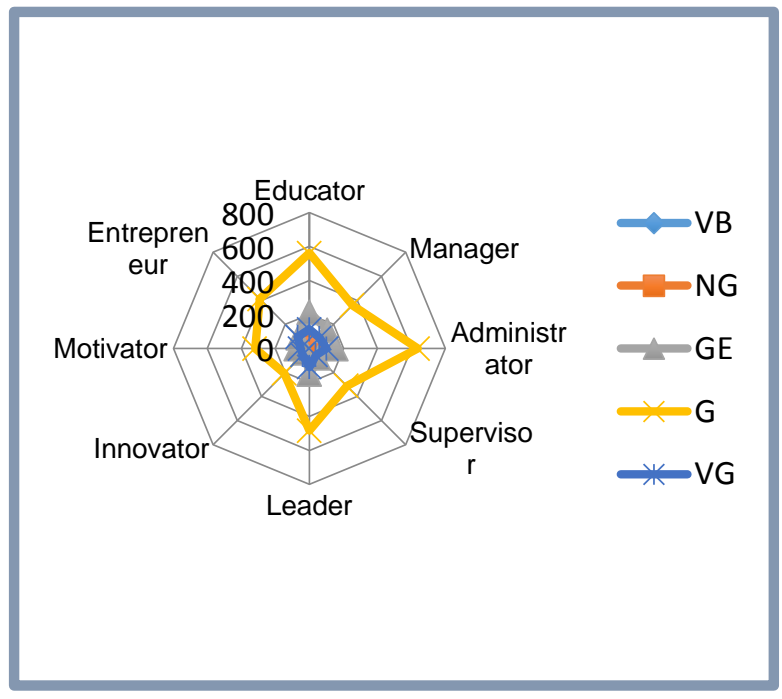

In the spider curve model it can be seen that on average the behavior performance of principals in senior high schools in Luwu Regency is "well categorized". The performance of the task and role of the principal in a tiered manner is best in its function, always administrators, educators, leaders, entrepreneurs, managers, motivators, supervisors and innovators. Without denying the quality of its performance it is clear that principals in high schools in Luwu Regency are actualized through the attitudes and behaviors played. 


\section{CONCLUSION}

The snapshot of the actualization of the functions and roles of principals in the EMASLIME acronym in senior high schools in Luwu Regency is seen through the ability of personal academics to carry out the principles of "good school governance" in the schools led. The leadership performance of the school principal was not only actualized in the good category, but also able to build the image of the school community and the surrounding community regarding the success of the high school in Luwu Regency as proof of the success (performance) of the principal.

\section{REFERENCE}

Akib, H. (2008). Reaktualisasi Fungsi dan Peranan Kepala Sekolah. Jurnal Tenaga Kependidikan, 3(2 Agustus).

Asumah, S. N., \& Nagel, M. (2014). Diversity, social justice, and inclusive excellence: Transdisciplinary and global perspectives. Albany, NY: State University of New York Press.

Cheng, Y. C. (2013). School effectiveness and school-based management: A mechanism for development. Routledge.

Cranston, N. C. (2002). School-based management, leaders and leadership: Change and challenges for principals. International Studies in Educational Administration, $30(1)$.

Danim, S., \& Suparno, A. (2008). Manajemen dan kepemimpinan Transformasional Kepala sekolah. Jakarta: Rineka Cipta.

Dempster, N. (2001). The Professional Development of School Principals: a fine balance.

Dharma, S., \& Akib, H. (2009). Kewirausahaan Sekolah Berbasis Kreativitas dan Inovasi. Jurnal Pendidikan Dan Kebudayaan, Edisi Khusus, 15(1), 102-117.

Dimmock, C. (2013). School-based management and school effectiveness. Routledge.

Duhan, S., Levy, M., \& Powell, P. (2001). Information systems strategies in knowledge-based SMEs: the role of core competencies. European Journal of Information Systems, 10(1), 25-40.

Dunham, J. (2003). Developing effective school management. Routledge.

Engels, N., Hotton, G., Devos, G., Bouckenooghe, D., \& Aelterman, A. (2008). Principals in schools with positive school culture. Educational Studies, 34(3), 159-174.

Everard, K. B., Morris, G., \& Wilson, I. (2004). Effective school management. Sage.

Gilley, J., \& Maycunich, A. (2000). Beyond the Learning Organization: Creating a Culture of Continuous Growth and Development through State-of-the-Art Human Resource Practices. Basic Books (AZ).

Ichijo, K. (2007). Enabling knowledge-based competence of a corporation. Knowledge Creation and Management: New Challenges for Managers, 83, 96.

Johnson, P. E., \& Short, P. M. (1998). Principal's leader power, teacher empowerment, teacher compliance and conflict. Educational Management \& Administration, 26(2), 147-159. 
INTERNATIONAL CONFERENCE ON PUBLIC

ORGANIZATION

ASIA PACIFIC SOCIETY FOR PUBLIC AFFAIRS (APSPA)

APSPA

Juffri, M., Akib, H., Ridjal, S., Sahabuddin, R., \& Said, F. (2018). Improving Attitudes and Entrepreneurial Behaviour of Students based on Family Environment Factors at Vocational High School in Makassar. Journal of Entrepreneurship Education, 21(2), 1-14.

Khotimah, K. (2013). Pengamalan Nilai Sipakatau, Sipakalibbi, Sipakainge, di Lingkungan Forum Komunikasi Mahasiswa Bone-Yogyakarta. THAQAFIYYAT: Jurnal Bahasa, Peradaban Dan Informasi Islam, 14(2), 202-229.

Kuehn, K. W. (2008). Entrepreneurial intentions research: Implications for entrepreneurship education. Journal of Entrepreneurship Education, 11, 87.

Maida, N. (2017). Pengasuhan Anak dan Budaya 3S (Sipakatau, Sipakainge dan Sipakalebbi) di Perkotaan. In Prosiding Seminar Nasional Himpunan Sarjana Ilmu-ilmu Sosial (Vol. 2, pp. 327-334).

Marquardt, M. (2011). Building the learning organization: Achieving strategic advantage through a commitment to learning. Nicholas Brealey Publishing.

Menteri Pendidikan dan Kebudayaan. (2018). Peraturan Menteri Pendidikan dan Kebudayaan Nomor 6 Tahun 2018 Tentang Penugasan Guru sebagai Kepala Sekolah. Jakarta, Indonesia.

Menteri Pendidikan Nasional Republik. (2007). Peraturan Menteri Pendidikan Nasional Nomor 13 tahun 2007 tentang Standar Kompetensi Kepala Sekolah/Madrasah. Jakarta, Badan Standar Nasional Pendidikan.

Mestry, R., \& Grobler, B. R. (2003). The training and development of principals in managing schools effectively. Education as Change, 7(2), 126-146.

Mestry, R., \& Grobler, B. R. (2004). The Training and Development of Principals to Manage Schools Effectively Using the Competence Approach. International Studies in Educational Administration, 32(3).

Murphy, J., \& Beck, L. G. (1995). School-Based Management as School Reform: Taking Stock. ERIC.

Pihie, Z. A. L., Asuimiran, S., \& Bagheri, A. (2014). Entrepreneurial leadership practices and school innovativeness. South African Journal of Education, 34(1).

Saggaf, M. S., Salam, R., \& Rifka, R. (2017). The Effect of Classroom Management on Student Learning Outcomes. In International Conference on Education, Science, Art and Technology (pp. 98-102).

Salam, R., \& Akib, H. (2014). The Impact of Policy on Region Expansion to Office Administrative Services In Barombong Subdistrict of Gowa District.

Shermon, G. (2005). Human Resource Based Competency. New Dehli.: Tata McGraw-Hill.

Singarimbun, M., \& Efendi, S. (1996). Metode Penelitian Survey. Jakarta, Indonesia: PT Pustaka LP3ES.

Singh, P., \& Dali, C. M. (2013). The value of empathy as an instructional leadership competency for school principals. Education as Change, 17(sup1), S65-S78.

Smith, G. A., \& Sobel, D. (2014). Place-and community-based education in schools. Routledge.

Sudrajat, A. (2008). "Kompetensi Kepala Sekolah. Diakses Dari Http: Ahmadsudrajat. Wordpress. Com, Tanggal, 22, 12.

Sugiyono. (2010). Metode Penelitian Kuantitatif, Kualitatif dan R\&D. Bandung: CV Alfabeta.

Sugiyono, D. R. (2006). Statistika untuk penelitian. Bandung: CV. Alfabeta.

Syam, A., Akib, H., Yunus, M., \& Hasbiah, S. (2018). Determinants of Entrepreneurship Motivation for Students at Educational Institution and Education Personnel in Indonesia. Journal of Entrepreneurship Education, 21(2), 1-12. 
Syam, H., Akib, H., Patonangi, A. A., \& Guntur, M. (2018). Principal Entrepreneurship Competence Based on Creativity and Innovation at the Context of Learning Organizations in Indonesia. Journal of Entrepreneurship Education, 21(3), 1-13.

Unru, A. B., \& Ismail, I. (2018). Memahami Budaya $3 S$ (Sipakatau, Sipakalebbi dan Sipakainge). (I. Ismail, Ed.). Makassar, Indonesia: Identitas Universitas Hasanuddin.

Usman, H. (2015). Model kepemimpinan instruksional kepala sekolah. Jurnal Cakrawala Pendidikan, 34(3).

Wahjosumidjo. (2005). Kepemimpinan Kepala Sekolah. Jakarta, Indonesia: PT. Raja Garfindo Persada.

Warren, M. R., Hong, S., Rubin, C. L., \& Uy, P. S. (2009). Beyond the bake sale: A community-based relational approach to parent engagement in schools. Teachers College Record, 111(9), 2209-2254.

Williams, H. W. (2008). Characteristics that distinguish outstanding urban principals: Emotional intelligence, social intelligence and environmental adaptation. Journal of Management Development, 27(1), 36-54.

Zahra, S. A., Nielsen, A. P., \& Bogner, W. C. (1999). Corporate entrepreneurship, knowledge, and competence development. Entrepreneurship Theory and Practice, 23(3), 169-189. 